\title{
Perio-Prosthodontics Considerations in Removable Partial Denture: The Role of the Prosthodontist
}

\author{
Muhammad Haider Amin Malik ${ }^{1}$ \\ BDS, FCPS \\ Nazia Yazdanie ${ }^{2}$ \\ BDS, FCPS, MSc, PhD
}

OBJECTIVE: To review the periodontal considerations associated with removable partial denture therapy. METHODOLOGY: Using a MEDLINE search, for "removable partial dentures periodontal", a total of 712 papers from peer-reviewed journals came in results. The MEDLINE search was made more specific by applying filters to the key phrase with other key words such as "periodontal evaluation"(140), "direct retainers"(77), "non-surgical periodontal"(8), "surgical periodontal"(180), "plaque"(249), "periodontal indices"(112), "tooth mobility,"(180) "periodontal maintenance,"(60) "splinting,"(198) and "split major connector"(2). Both in vivo and in vitro studies on the Perio-prosthodontic aspects of RPD treatment were included in the study pool whereas case Series and case reports were excluded.

RESULT: A total of 1206 studies were collected from the search engine. After applying the exclusion criteria and filtering the duplicates a total of 95 studies were included for the narrative review.

CONCLUSIONS: Out of all the factors, recall and oral and denture hygiene have the utmost importance.

KEYWORDS: Perio-prosthodontics, removable partial denture, periodontal indices.

HOW TO CITE: Malik MHA, Yazdanie N. Perio-prosthodontics considerations in removable partial denture: the role of the prosthodontist. J Pak Dent Assoc 2021;30(3):219-227.

DOI: https://doi.org/10.25301/JPDA.303.219

Received: 09 August 2020, Accepted: 12 March 2021

\section{INTRODUCTION}

$\mathrm{T}$ he relationship between periodontal health and restoration of teeth is intimate and inseparable. For restoration to survive long term, the periodontium must remain healthy so that the teeth are retained. ${ }^{1,2}$ Periodontics and prosthodontics share this interdisciplinary coordination in multiple aspects: treatment plan, procedures execution, outcome achievement and maintenance. To facilitate this collaboration, the Prosthodontist should appreciate the Periodontic implications of various restorative procedures..$^{2-4}$

Fixed and removable prosthesis supported by oral mucosa, natural teeth or dental implants are provided to patients according to their indications. ${ }^{5}$ There may be situations where systemic health, oral conditions, financial constraints or time constraints preclude the use of fixed prosthesis in the patient. ${ }^{2}$ Due to oral tissue preservation, the Removable partial dentures (RPDs) are a best choice as an alternate treatment option. ${ }^{6,7}$ However, for most of the patients the fixed prosthesis is more desirable from a

1. Senior Registrar, Department of Prothodontics, Fatima Memorial Hospital, College of Dentistry, Lahore.

2. Professor, Head of Department, Principal, Department of Prothodontics, Fatima Memorial Hospital, College of Dentistry, Lahore.

Corresponding author: "Dr. Muhammad Haider Amin Malik"

$<$ haiderbds@gmail.com > psychological point of view. ${ }^{6,8-10}$ Successful treatments by RPDs require thorough insight on the effect and interactions of the RPD with the oral tissues. ${ }^{4}$ The purpose of this article is to review the dental literature regarding Perio-prosthetic considerations in RPDs.

Using a MEDLINE search, for "removable partial dentures periodontal", a total of 712 papers from peerreviewed journals came in results. The MEDLINE search was made more specific by applying filters to the key phrase with other key words such as "periodontal evaluation"(140), "direct retainers"(77), "non-surgical periodontal"(8), "surgical periodontal"(180), "plaque"(249), "periodontal indices"(112), "tooth mobility,"(180) "periodontal maintenance,"(60) "splinting,"(198) and "split major connector"(2). Both in vivo and in vitro studies on the Perio-prosthodontic aspects of RPD treatment were included in the study pool whereas case Series and case reports were excluded. A total of 1206 studies were collected from the search engine. After applying the exclusion criteria and filtering the duplicates a total of 95 studies were included for the narrative review.

\section{Pre prosthetic periodontal evaluation phase}

The periodontal examination of a patient for any type of prosthetic treatment is important for the prognosis and success of treatment. ${ }^{11,12}$ The periodontal examination must include the status of Oral hygiene, status of bacterial 
accumulation, degree of reversible and irreversible damage to periodontal tissues, gingival biotype, functional and static occlusion and mobility of teeth. The objective at this stage is to diagnose any periodontal conditions that would either compromise the construction of the denture or compromise the prognosis for a successful therapeutic outcome. ${ }^{13,14}$ Overhanging fillings, open margins of existing restoration, over-contoured restorations, severely tilted teeth and furcation involvements increase the bacterial accumulation in the oral cavity. These plaque retentive features must be minimized or removed before proceeding to a definite prosthetic treatment. Likewise, immune status of host and response to previous periodontal and prosthodontic therapies is also important. ${ }^{2,3,14}$ Periodontal loss in young patients has poorer prognosis than the older patients because in the younger patients the disease has taken a more virulent course.

A quick assessment of the patient's level of education and motivation of oral and denture hygiene is necessary as it is critical to success of RPDs. ${ }^{3,14}$ This process of learning and encouragement should be a part of each appointment of the treatment and post treatment recalls. ${ }^{15}$ In RPDs there is more coverage of hard and soft tissue than FPDs therefore the Oral hygiene is even more crucial for these patients. ${ }^{16-18}$

Finally medical status of the patient must be evaluated. Medical conditions can either have a local implication on the overall health status of the periodontal tissues or they can affect the prognosis of any restorative treatment on the abutment teeth. ${ }^{19}$ Failure to appreciate any underlying systemic condition or any medication that can affect the periodontium may cause serious setbacks and failures of the restorative treatment. According to Leyvee et al, abutment teeth with good periodontal prognosis have a 9.3 lower risk of tooth loss than the teeth with lower prognostic values. ${ }^{20}$

\section{Pre prosthetic periodontal procedures Non-Surgical Procedures}

Routine non-surgical periodontal care has two basic components: Effective daily plaque removal by the patient and Supportive periodontal therapy (SPT) every 2 to 6 months. ${ }^{21-24}$ Generally patients are not able to remove all the plaque from all surfaces of teeth throughout the day but a good immune system can resist detrimental effects of residual plaque..$^{23,25-27}$ Being the most conservative and non-invasive periodontal treatment, Scaling and root planning (SC/RP) is also termed as the basic supportive periodontal therapy (SPT) ${ }^{28-30}$ This therapy can give the greatest level regain of the clinical attachment loss as compared to any other therapeutic technique..$^{22,30,31}$ It also aids in an improvement in oral microbial composition which in turn, helps in reduction of pocket depth and also reduction in bleeding sites. It is cost effective and has minimal side effects in comparison to surgical techniques..$^{24,32}$

\section{Surgical Procedures}

Surgical periodontal therapy is indicated in cases where ${ }^{2,33-35}$

1. Continued bone loss in a patient who has had SC/RP and is on a 2- to 3-month periodontal maintenance schedule

2. The need for making more cleansable gingival contours.

3. The need to clean root surface that are in accessible non-surgically.

Though Surgical periodontal therapies help maintain a healthy periodontal status however they have their own biological costs. If health of periodontium is not maintained by a regular SPT, any type of surgical procedure may fail to give favorable outcomes. ${ }^{34,36,37}$

\section{Effect of Removable Partial Dentures on Plaque}

RPD wearing has been associated with alteration in quantity and quality of plaque..$^{38-45}$ Addy and Bates stated that, whether a denture design is either close fitting or self-cleansing, plaque accumulation is higher with patients that have poor oral hygiene. ${ }^{44}$ In a series of studies Ghamrawy E. et al have stated that plaque formation is enhanced on abutment teeth with increase proliferation of Spirilla and spirochetes than other bacterial strains. ${ }^{40-42}$ Thus special tooth brushing techniques must be advocated to patients wearing RPDs as they are at high risk of developing periodontal disease. ${ }^{41}$ Bissada evaluated gingival response to coverage by partial dentures. ${ }^{46}$ All the design features were similar for these dentures except the relationship of the gingival tissues to the palatal plate and the material of denture. The results of the study showed that the coverage of gingival areas by RPD without relief and the acrylic based dentures showed overt periodontal inflammation that is appreciable both clinically and histologically, whereas the areas left uncovered by denture were the least affected. Based on the results of this study a minimum distance of 5 to 6 $\mathrm{mm}$ away from the free gingival margins for major connectors was proposed. Similar observations were made in other studies on plaque accumulation due to RPD use. They concluded that a meticulous and persistent level of oral hygiene is required for patients wearing patients. They also stated that the denture design should simple and minimalistic, thus it should cover only those hard and soft tissues that are required. ${ }^{47-49}$

Wearing of RPD may promote the formation of plaque but if meticulous oral and denture hygiene is practiced by the patient then it can be effectively control. In a study the 
authors demonstrated that just by teaching patients meticulous tooth brushing, plaque can be controlled. ${ }^{48}$ The hygiene measures that the literature supports includes; using special toothbrushes for proximal surfaces, frequent cleaning of the dentures and tooth brushing after each meal. ${ }^{41}$ Thus, it can be extracted from the literature that the wearing of RPD may promote plaque formation but the major factors are related to poor oral and denture hygiene.

\section{Effect of Removable partial dentures on periodontal indices}

FPDs have a general repute of being a better treatment option than the RPDs amongst the less experienced dental community and patients. This biased notion has been made due to several reasons. ${ }^{50-52}$

RPD is given in a patient that is not suitable for any fixed restoration either because of poor abutments and/or poor periodontal status of patient. Thus RPD wearing patients that have a compromised prognosis of remaining teeth, make a larger number.

Complications of FPDs are less reported by patients and less observed by the dentists because the periodontium has a better tolerance for abuse and trauma than oral mucosa. Thus if factors like oral hygiene, prosthesis design and case selection were to be kept constant, the clinical outcomes related to periodontal health would not differ both for RPDs or FPDs. ${ }^{51}$

If oral hygiene and denture hygiene measures are meticulously followed by patients, there appears to be no correlation of poor periodontal indices and RPDs. ${ }^{51-54}$ However few studies have attributed RPDs with worsening of periodontal indices of abutment teeth as compared to non-abutment teeth. ${ }^{50,55}$ The crux of this reported variation of result lies in the difference of oral and denture hygiene by the patient. ${ }^{52,56,57}$ It is recommended that Recall visits should be planned to intercept the development of periodontal pockets. ${ }^{58}$

\section{Effect of removable partial dentures on tooth mobility}

Mobility of natural teeth can be physiological or pathologica. ${ }^{59}$ The clinical mobility of tooth is classified by numerous periodontal indices which have different criteria of assessment and classification. ${ }^{60}$ One of the pathological causes of tooth mobility is periodontal disease. Periodontal disease causes the alveolar bone to resorb and minimizes the volume and quality of the supportive tissues of the tooth.61 Partial dentures are associated with increased tooth mobility of abutment teeth, which may be attributed to increase forces on abutments or dental plaque accumulation. ${ }^{62-64}$ Rigid Metal major connector directs less forces on abutment teeth than a non-rigid polymer based major connector. ${ }^{65}$ However care in planning and designing of RPD on a dental surveyor, selection of abutments and harmonizing occlusal contacts can decrease this harmful effect of RPDs on the natural teeth. ${ }^{38,61,66}$ If oral and denture hygiene are taken care of, forces from RPDs alone may not cause abutment tooth mobility. ${ }^{57}$

\section{Effect of Components of removable partial denture on periodontal status of abutments Direct retainer design}

Direct retainers vary in shape, origin and materials according to the suitability and requirement of partially dentate situation. ${ }^{67}$ Direct retainers are considered to cause gingival recession and increase caries of abutment teeth. ${ }^{68-74}$ However if retainers are placed according to survey line and well supported by rests, they will not cause any harm to periodontal tissue. ${ }^{67,75}$ Some studies have showed that precision attachments are less damaging to periodontium than the clasp type retainers; this may be due to better vertical loading of abutments teeth. ${ }^{74,76-79}$ For distal extension bases mesial rest with I bar retainers were proven to be more favorable for longevity of abutment teeth. ${ }^{72,73,75,76,78-82}$ For periodontally compromised abutments bar retainers in the clasp type retainers and non-rigid retainers in the attachments type retainers were found to be favorable for periodontal health of abutment teeth than any other types of retainers. ${ }^{66,73-75,78-83}$ Newer composite materials have comparable retentive and mechanical properties as compared to cobalt chromium clasp. ${ }^{84}$ Clasps made out of PEEK (Poly ether ether ketone) were found to have less flexural strength than cobalt chromium clasps.$^{85}$, thus to achieve retention they would be made wider than cobalt chromium clasps, which may cause increase in plaque accumulation.

\section{Major and Minor connector design}

A basic design principle for removable partial denture is to extend the dentures on to supporting tissues and minimize the coverage of marginal gingival tissues. ${ }^{81}$ Marginal gingiva that is loosely attached to the alveolar bone is prone to stripping from contact with denture components especially the major connectors. ${ }^{76,81,86-88}$ This stripping is due to the lack of well supported occlusal rests or excessive coverage of components over the gingival collar. ${ }^{87-91}$ As a design principle a minimum of 4-6mm of distance should be kept between marginal gingiva and borders of Major connector. ${ }^{15,46}$

\section{Denture Framework materials}

Traditionally metal has been used for denture framework for RPDs but with advent of new materials various non-metallic materials have been used for Denture framework such as PEEK. The advantage of PEEK over metal denture framework materials is that its modulus of elasticity closely 
matches to that of alveolar bone. In a study by Xin et al, it was shown that due to flexibility of framework made by PEEK, forces on abutment teeth were less than other metallic denture framework; however the forces on mucosa were increased specially in the distal extension bases. Thus for patients with poor periodontal status of remaining teeth, PEEK may be used as a denture framework but for distal extension bases it is not recommended. ${ }^{92}$ In another study, High impact denture resin was compared with cobalt chromium RPDs. There was no statistical and clinical difference in outcomes of periodontal health in both materials. ${ }^{93}$ However, Itoh et al concluded that rigidity of major connector is associated with decreased abutment mobility. ${ }^{65}$

\section{Split Major Connectors}

Stress breaking phenomena is of paramount importance in minimizing forces on abutment tooth. While various clasps are designed to disengage the abutment tooth during physiological movement of distal extension base; the Split Major Connectors or Stress breakers are designed to decrease torqueing forces to the abutment teeth during physiological movement of distal extension base dentures. ${ }^{94}$

Henderson and Steffen suggested a split lingual bar to redirect the torqueing forces on the abutment tooth. ${ }^{13}$ Photo elastic studies were done by Reitz et al. prove the efficacy of split major connectors in both maxillary and mandibular arch. ${ }^{94,95}$ For maxillary major connector he stated that the split palatal major connector reduced the forces directed to the distal-extension abutment and transferred to the regions underlying the denture base. For mandibular major connector he stated that ${ }^{95,96}$

1. In short distal extension bases, there is no significant reduction of force on abutments by use of split major connector.

2. If the split of major connector extends to the midline, the stress on the distal-extension abutment is not only in a more vertical direction but also has less magnitude.

3. In the long distal extension denture bases, the stress was increased on the alveolar bone.

\section{Effect of splinting of abutments}

Few in-vitro photoelastic studies suggested that at least two abutment teeth should be splinted in distal extension bases for reduction of stresses especially when periodontal support in compromised. ${ }^{97,98}$ In some studies it was suggested that fixed splinting of abutment teeth should be done when attachment are used for distal extension bases..$^{70,81}$ Splinting of abutment tooth is associated with less abutment movement than non-splinted abutments. ${ }^{77,99}$ Carlson reported that in addition to splinting of abutments the other main factors included denture hygiene and gingival relief for successful RPDs. ${ }^{98}$ No clinical study was found on this subject.

\section{Effect of impression technique}

Impression making is a fundamental step for establishing the attributes of the denture i.e. support, stability and retention. Impression making of distal extension bases must accommodate the function movement of denture base. Stability of denture base and load sharing with teeth is directly related to amount of contact of supporting mucosa with major connector. ${ }^{100}$ An in vivo study compared the functional movement of distal extension RPD bases made by three different impression techniques; (a) an altered-cast impression, (b) an impression made from a border-molded custom tray, (c) an irreversible hydrocolloid impression in a stock tray. The altered cast impression had less movement of distal extension base in that can be clinically significant because mucosal support has an indispensable role of sharing the occlusal load with the abutment teeth in distal extension RPDs. ${ }^{101}$ A recent systematic review reported that there is not enough advantage of altered cast impression over one piece cast. ${ }^{102}$ This is because of lack of data to prove that altered cast impression is better than any other technique for distal extension removable dental prosthesis impressions. The article also emphasizes that there is need for more scientific research with larger sample sizes and longer performance reviews.

\section{Periodontal Maintenance in recall appointments}

Recall appointments are necessary for both periodontal and prosthetic maintenance for patients wearing RPDs. However these are not well maintained in all the dental facilities especially where students' work. ${ }^{103}$ Periodic recall appointments aid in early diagnosis of a periodontal diseases or a prosthetic condition which are easier to control in the early stages. ${ }^{103,104}$ The frequency of these recalls depends on the need of individual patient, because of the variation in immune status, denture biomechanics and plaque control. Distorted or damaged components of dentures, Ill-fitting dentures, changes in occlusion, and signs of Parafunction and poor denture hygiene can render the RPDs useless or even dangerous. Thus a timely intervention can save undesirable trauma to the remaining teeth and soft tissues..$^{58,105,106}$

\section{Conclusion}

Considering all the above stated literature, there are many factors of periodontal health in patients wearing removable partial denture, however the most fundamental factors are Recall appointments and Oral and denture hygiene which 
are usually ignored in most of the practices. Therefore, it is of utmost importance that the dentists must follow up with their patients and keep a record of their periodontal health because prevention is better than cure. The designing of the prosthesis must foresee the periodontal implication of the individual components.

\section{CONFLICT OF INTEREST}

None to declare

\section{REFERENCES}

1. Bergman B. Periodontal reactions related to removable partial dentures: A literature review. J Prosthet Dent 1987;58:454-58. https://doi.org/10.1016/0022-3913(87)90275-7

2. Petridis H, Hempton TJ. Periodontal Considerations in Removable Partial Denture Treatment : Int J Prosthodont 2001;14:164-72.

3. Budtz-Jörgensen E. Restoration of the partially edentulous mouth - A comparison of overdentures, removable partial dentures, fixed partial dentures and implant treatment. J Dent 1996;24:237-44. https://doi.org/10.1016/0300-5712(95)00075-5

4. H. E. The role of the prosthodontist in the treatment of periodontal disease. J, Int Dent 1986;36:18-29.

5. Wöstmann B, Budtz-Jørgensen E, Jepson N, Mushimoto E, Palmqvist S SA. Indications for removable partial dentures: a literature review. Prosthodont Int J 2005;18139-46.

6. Rojas-Torres J, Navarro-Cáceres P, Fonseca GM. Attitudes, Perceptions, and Preferences of Individuals from Temuco (Chile) About Denture Marking. J Forensic Sci 2019; 64: 1187-195. https://doi.org/10.1111/1556-4029.13991

7. Dhingra K. Oral Rehabilitation Considerations for Partially Edentulous Periodontal Patients. J Prosthodont 2012;21:494-513. https://doi.org/10.1111/j.1532-849X.2012.00864.x

8. Kapur KK. Veterans administration cooperative dental implant study-comparisons between fixed partial dentures supported by bladevent implants and removable partial dentures. Part IV: Comparisons of patient satisfaction between two treatment modalities. J Prosthet Dent 1991;66:517-29.

https://doi.org/10.1016/0022-3913(91)90516-Y

9. Garrett N, Roumanas ED, Blackwell KE, Freymiller E, Abemayor E, Wong WK et al. Efficacy of conventional and implant-supported mandibular resection prostheses: Study overview and treatment outcomes. J Prosthet Dent 2006;96:13-24.

https://doi.org/10.1016/j.prosdent.2006.05.010

10. McKenna G, Tada S, Woods N, Hayes M, DaMata C, Allen PF. Tooth replacement for partially dentate elders: A willingness-to-pay analysis. J Dent 2016;53:51-6.

https://doi.org/10.1016/j.jdent.2016.07.006
11. Franzetti JJ. Symposium. Symposium on semiprecision attachments in removable partial dentures. Periodontal considerations and guidelines for therapy. Dent Clin North Am 1985;29:17-38.

12. Gomes BC RR. Periodontal considerations of the removable partial overdenture. Gomes. Dent Clin North Am 1990;34:653-68.

13. McGivney GP CD. Preparation of mouth for removable partial dentures. In: McCracken's Removable Partial Dentures. 8th ed. 1989.

14. Isidor F B-JE. Periodontal conditions following treatment with distally extending cantilever bridges or removable partial dentures in elderly patients. A 5-year study. J. J Periodontol 1990;61:21-6. https://doi.org/10.1902/jop.1990.61.1.21

15. Owall, Bengt \& Budtz-Jörgensen, Ejvind D. Removable Partial Denture Design: A Need to Focus on Hygienic Principles?. Int J Prosthodont 2000. AD;15:371-78.

16. E. G. Qualitative changes in dental plaque formation related to removable partial dentures. J Oral Rehabil 1979;6:183-88.

https://doi.org/10.1111/j.1365-2842.1979.tb01279.x

17. Ghamrawy E. Quantitative changes in dental plaque formation related to removable partial dentures. J Oral Rehabil 1976 1976; 3: 115-120.

https://doi.org/10.1111/j.1365-2842.1976.tb00935.x

18. Mihalow DM TN. The influence of removable partial dentures on the level of Streptococcus mutans in Saliva. J Prosthet Dent 1988; 59: 49-51.

https://doi.org/10.1016/0022-3913(88)90107-2

19. Al Deeb M, Abduljabbar T, Vohra F, Zafar MS, Hussain M. Assessment of factors influencing oral health-related quality of life (OHRQoL) of patients with removable dental prosthesis. Pakistan J Med Sci 2020;36:213-18.

https://doi.org/10.12669/pjms.36.2.1257

20. Leyvee Lynn L Cabanilla ALN, Hernandez F. The relationship between periodontal diagnosis and prognosis and the survival of prosthodontic abutments: a retrospective study. Quintessence Int (Berl) 2009;40:821-31.

21. Reddy MS et al. Periodontal disease progression. J Periodontol 2000;71:1583-588.

https://doi.org/10.1902/jop.2000.71.10.1583

22. J S. Low-cost periodontal therapy. J Periodontol 2012; 60: 110-121.

https://doi.org/10.1111/j.1600-0757.2011.00429.x

23 Sanz I et al. Nonsurgical treatment of periodontitis. J Evid Based Dent Pr 2012; 12:76-86. https://doi.org/10.1016/S1532-3382(12)70019-2

24. Heitz-Mayfield LJA LN. Surgical and nonsurgical periodontal therapy. Learned and unlearned concepts. J Periodont 2000; 62: 218-31. https://doi.org/10.1111/prd.12008 
25. Weinberg MA HH. Bleeding on probing: what does it mean? Gen Dent 60 2012; 60: 271-82.

26. MA Listgarten. Periodontal probing: what does it mean? J Clin Periodontol 1980; 7: 165-70.

https://doi.org/10.1111/j.1600-051X.1980.tb01960.x

27. DE M. A practical approach to the diagnosis and treatment of periodontal disease. J Am Dent Assoc 2000;131:483-87.

https://doi.org/10.14219/jada.archive.2000.0205

28. Kinney JS et al: Oral fluid-based biomarkers of alveolar bone loss in periodontitis. Ann N Y Acad Sci 2007;230:1098-103. https://doi.org/10.1196/annals.1384.028

29. Hallmon WW RT. Local anti-infective therapy: mechanical and physical approaches.A systematic review. Ann Periodontol 2003; 8: 99-104.

https://doi.org/10.1902/annals.2003.8.1.99

30. JM G. Diagnosis of periodontitis by physical measurement: interpretation from episodic disease hypothesis. J Periodontol 1992; 63: 373-79.

https://doi.org/10.1902/jop.1992.63.4s.373

31. CH D. Nonsurgical periodontal therapy. J Periodontol 2001; 25 : 77-83.

https://doi.org/10.1034/j.1600-0757.2001.22250106.x

32. Belstrøm D et al. Differences in bacterial saliva profile between periodontitis patients and a control cohort. J Clin Periodontol 41(2)104, 2014;4":104-08.

https://doi.org/10.1111/jcpe.12190

33. Hempton TJ DJ. Contemporary crown-lengthening therapy: a review. J Am Dent Assoc 2010;141:647-60.

https://doi.org/10.14219/jada.archive.2010.0252

34. Pihlstrom BL et al. Comparison of surgical and nonsurgical treatment of periodontal disease. A review of current studies and additional results after 6 1/2 years. J Clin Periodontol 1983;10:52436.

https://doi.org/10.1111/j.1600-051X.1983.tb02182.x

35. Nyman $\mathrm{S}$ et al. Periodontal surgery in plaque- infected dentitions. J Clin Periodontol 1977;4:240-51. https://doi.org/10.1111/j.1600-051X.1977.tb01896.x

36. Rylander H. Changing concepts of periodontal treatment: surgical and non-surgical. Int Dent J 1988;38:163-75.

37. Russo NM Dello. Gingival autografts as an adjunct to removable partial dentures. J Am Dent Assoc 1982;104:179-81.

https://doi.org/10.14219/jada.archive.1982.0009

38. Zlataric DK, Celebic A, Valentic-Peruzovic M. The Effect of Removable Partial. J Periodontol 2002;73:137-44.

https://doi.org/10.1902/jop.2002.73.2.137

39. Davenport JC, Basker RM, Heath JR, Ralph JP, Glantz PO.
Prosthetics: The removable partial denture equation. Br Dent J 2000; 189:41424.

https://doi.org/10.1038/sj.bdj.4800787

40. EL Ghamrawy E. Qualitative changes in dental plaque formation related to removable partial dentures. J Oral Rehabil 1979; 6:183-88. https://doi.org/10.1111/j.1365-2842.1979.tb01279.x

41. Ghamrawy E EL, Tryde G. Plaque recordings as a guide to the prognosis for partial denture treatment. J Oral Rehabil 1980;7:11721.

https://doi.org/10.1111/j.1365-2842.1980.tb00427.x

42. Ghamrawy EE. Qualitative changes in dental plaque formation related to removable partial dentures. J Oral Rehabil 1979; 6: 183-88. https://doi.org/10.1111/j.1365-2842.1979.tb01279.x

43. Shimura Y, Wadachi J, Nakamura T, Mizutani H, Igarashi Y. Influence of removable partial dentures on the formation of dental plaque on abutment teeth. J Prosthodont Res 2010; 54:29-35. https://doi.org/10.1016/j.jpor.2009.08.003

44. Bates JF, Addy M. Partial dentures and plaque accumulation. J Dent 1978;6:285-93.

https://doi.org/10.1016/0300-5712(78)90163-X

45. Mihalow DM, Tinanoff N. Influence of removable partial dentures on the Streptococcus mutans level in saliva. Soproden 1989;5:24547.

46. Bissada NF, Ibrahim SI, Barsoum WM. Gingival Response to Various Types of Removable Partial Dentures. J Periodontol 1974; 45:651-59.

https://doi.org/10.1902/jop.1974.45.9.651

47. Yusof Z, ISA Z. Periodontal status of teeth in contact with denture in removable partial denture wearers. J Oral Rehabil 1994; 21: 77-86.

https://doi.org/10.1111/j.1365-2842.1994.tb01126.x

48. Tada S, Allen PF, Ikebe K, Matsuda KI, Maeda Y. Impact of periodontal maintenance on tooth survival in patients with removable partial dentures. J Clin Periodontol 2015;42:46-53.

https://doi.org/10.1111/jcpe.12320

49. ADDY M, BATES JF. Plaque accumulation following the wearing of different types of removable partial dentures. J Oral Rehabil 1979; 6:111-17.

https://doi.org/10.1111/j.1365-2842.1979.tb01271.x

50. Käyser AF, Witter DJ, Spanauf AJ. Overtreatment with removable partial dentures in shortened dental arches. Aust Dent J 1987;32:17882.

https://doi.org/10.1111/j.1834-7819.1987.tb01851.x

51. Zarb GA, MacKay HF. The partially edentulous patient. I. The biologic price of prosthodontic intervention. Aust Dent J 1980; 25: 63-8.

https://doi.org/10.1111/j.1834-7819.1980.tb03676.x 
52. Zarb GA, MacKay HF. The partially edentulous patient. II. A rationale for treatment. Aust Dent J 1980;25:152-62. https://doi.org/10.1111/j.1834-7819.1980.tb03706.x

53. Dula LJ, Ahmedi EF, Lila-Krasniqi ZD, Shala KS. Clinical Evaluation of Removable Partial Dentures on the Periodontal Health of Abutment Teeth: A Retrospective Study. Open Dent J 2015;9:13239.

https://doi.org/10.2174/1874210601509010132

54. Costa L, do Nascimento C, de Souza VOP, Pedrazzi V. Microbiological and clinical assessment of the abutment and non-abutment teeth of partial removable denture wearers. Arch Oral Biol 2017;75:74-80.

https://doi.org/10.1016/j.archoralbio.2016.11.002

55. da Fonte Porto Carreiro A, de Carvalho Dias K, Correia Lopes AL, Bastos Machado Resende CM, Luz de Aquino Martins AR. Periodontal Conditions of Abutments and Non-Abutments in Removable Partial Dentures over 7 Years of Use. J Prosthodont 2017; 26:644-49. https://doi.org/10.1111/jopr.12449

56. Kern M, Wagner B. Periodontal Findings in patients 10 years after insertion of removable partial dentures. J Oral Rehab 2001;28:991-97. https://doi.org/10.1046/j.1365-2842.2001.00788.x

57. King J, Gibbs H. Occlusal considerations i n periodontology. Periodontol 2000 1995; 9:106-17.

https://doi.org/10.1111/j.1600-0757.1995.tb00059.x

58. R, Tuominen, K, Ranta P. Wearing of removable partial dentures in relation to periodontal pockets. J Oral Rehabil 1989; 16: 119-126. https://doi.org/10.1111/j.1365-2842.1989.tb01325.x

59. Frechette AR. The influence of partial denture design on distribution of force to abutment teeth. J Prosthet Dent 1956;6:195-212. https://doi.org/10.1016/0022-3913(56)90114-7

60. Karthikeyan, Varadhan SP. Tooth mobility measurements; Realities and Limitations. J Evol Med Dent Sci 2019;8:1342-350.

https://doi.org/10.14260/jemds/2019/298

61. Knezovic Zlataric D, Celebic A, Valentic-Peruzovic M. The Effect of Removable Partial Dentures on Periodontal Health of Abutment and Non-Abutment Teeth. J Periodontol 2002;73:137-44.

https://doi.org/10.1902/jop.2002.73.2.137

62. Ko SH, McDowell GC, Kotowicz WE. Photoelastic stress analysis of mandibular removable partial dentures with mesial and distal occlusal rests. J Prosthet Dent 1986; 56: 454-60.

https://doi.org/10.1016/0022-3913(86)90388-4

63. Bae E Bin, Kim SJ, Choi JW, Jeon YC, Jeong CM, Yun MJ et al. A clinical retrospective study of distal extension removable partial denture with implant surveyed bridge or stud type attachment. Biomed Res Int 2017; 1: 1-6.

https://doi.org/10.1155/2017/7140870

64. Ezzoli, Rossetto C. Soft vinyl stents to facilitate augmentation. J Prosthet Dent 1986;56:329-37.
65. $\mathrm{Al}$ itoh et. Effect of direct retainer and major connector designs on RPD and abutment tooth movement dynamics. J Oral Rehabil 2008; 35:810-15.

https://doi.org/10.1111/j.1365-2842.2008.01868.x

66. Tebrock OC, Rohen RM, Fenster RK, Pelleu GB. The effect of various clasping systems on the mobility of abutment teeth for distalextension removable partial dentures. J Prosthet Dent 1979; 41: 51116.

https://doi.org/10.1016/0022-3913(79)90082-9

67. Sadek SA, Dehis WM, Hassan H. Different materials used as denture retainers and their colour stability. Open Access Maced J Med Sci 2018;6:2173-179.

https://doi.org/10.3889/oamjms.2018.415

68. Chou TM, Caputo AA, Moore DJ, Xiao B. Photoelastic analysis and comparison of force-transmission characteristics of intracoronal attachments with clasp distal-extension removable partial dentures. J Prosthet Dent 1989;62:313-19.

https://doi.org/10.1016/0022-3913(89)90339-9

69. Mine K, Fueki K, Igarashi Y. Microbiological risk for periodontitis of abutment teeth in patients with removable partial dentures. J Oral Rehabil 2009; 36:696-702.

https://doi.org/10.1111/j.1365-2842.2009.01982.x

70. Chou TM, Eick JD, Moore DJ, Tira DE. Stereophotogrammetric analysis of abutment tooth movement in distal-extension removable partial dentures with intracoronal attachments and clasps. J Prosthet Dent 1991; 66: 343-49.

https://doi.org/10.1016/0022-3913(91)90261-T

71. Ogata K, Ishii A, Nagare I. Longitudinal study on torque transmitted from a denture base to abutment tooth of a distal extension removable partial denture with circumferential clasps. J Oral Rehabil 1992; 19: 245-52.

https://doi.org/10.1111/j.1365-2842.1992.tb01099.x

72. Ogata K. Longitudinal study on torque around the sagittal axis in lower distal-extension removable partial dentures. J Oral Rehabil 1993;20:203-11.

https://doi.org/10.1111/j.1365-2842.1993.tb01602.x

73. Thompson WD, Coputo A, Ph D. Evaluation of pheteelastic stress patterns produced by various design of bilateral distal extention removable partial denture. J Prosthet Dent 1977;38:261-73. https://doi.org/10.1016/0022-3913(77)90303-1

74. Wang HY, Zhang YM, Yao D, Chen JH. Effects of rigid and nonrigid extracoronal attachments on supporting tissues in extension base partial removable dental prostheses: A nonlinear finite element study. J Prosthet Dent 2011;105:338-46.

https://doi.org/10.1016/S0022-3913(11)60066-8

75. Krol AJ. Clasp design for extension-base removable partial dentures. J Prosthet Dent 1973;29:408-15. https://doi.org/10.1016/S0022-3913(73)80018-6

76. Kapur KK, Deupree R, Dent RJ, Hasse AL. A randomized clinical 
trial of two basic removable partial denture designs. Part I: Comparisons of five-year success rates and periodontal health. J Prosthet Dent 1994; 72:268-82.

https://doi.org/10.1016/0022-3913(94)90340-9

77. Goodkind J. The effects of removable partial dentureson abutment tooth mobility: A clinical study. J pros dent 1973; 30:139-46. https://doi.org/10.1016/0022-3913(73)90047-4

78. Lambert, J. Stumpel RWS. Use of a multifunctional precision. J pros dent 1991; 65:335-38.

https://doi.org/10.1016/0022-3913(91)90220-Q

79. Shahmiri R, Das R. Finite Element Analysis of Implant-Assisted Removable Partial Denture Attachment with Different Matrix Designs During Bilateral Loading. Int J Oral Maxillofac Implants 2016; 31 : 116-27.

https://doi.org/10.11607/jomi.4400

80. Benson D, Spolsky VW. A clinical evaluation of removable partial dentures with I-bar retainers. Part I. J Prosthet Dent 1979;41: 246-54.

https://doi.org/10.1016/0022-3913(79)90002-7

81. Akaltan F, Kaynak D. An evaluation of the effects of two distal extension removable partial denture designs on tooth stabilization and periodontal health. J Oral Rehabil 2005;32:823-29.

https://doi.org/10.1111/j.1365-2842.2005.01511.x

82. Müller S, Eickholz P, Reitmeir P, Eger T. Long-term tooth loss in periodontally compromised but treated patients according to the type of prosthodontic treatment. A retrospective study. J Oral Rehabil 2013; 40:358-67.

https://doi.org/10.1111/joor.12035

83. Caputo AA. Abutments Removable Partial With Reduced Periodontal Support. J Prosthet Dent 1993;70:245-50.

https://doi.org/10.1016/0022-3913(93)90059-W

84. Urano S. Bending Properties of Ce-TZP/A Nanocomposite Clasps for Removable Partial Dentures. Int J Prosthodon 2015; 28: 191-97. https://doi.org/10.11607/ijp.4113

85. Paulo J, Tribst M, Maria A, Dal DO, Luiz A, Borges S et al. Effect of different materials and undercut on the removal force and stress distribution in circumferential clasps during direct retainer action in removable partial dentures. Dent Mater 2019;1-8.

86. Ao A, Wakabayashi N, Nitta H, Igarashi Y. Clinical and Microbiologic Effects of Lingual Cervical Coverage by Removable Partial Dentures. Int J Prosthodont 2013; 26:45-50.

https://doi.org/10.11607/ijp.3061

87. Ogunrinde TJ, Dosumu OO, Shaba OP, Akeredolu PA, Ajayi MD. The influence of the design of mandibular major connectors on gingival health. Afr J Med Med Sci 2014; 43:29-33.

88. Orr S, Linden GJ, Newman HN. The effect of partial denture connectors on gingival health. J Clin Periodontol 1992;19:589-94. https://doi.org/10.1111/j.1600-051X.1992.tb00688.x
89. Lechner SK. Partial dentures and gingival health. 1963; 208: 1963966.

90. Ribeiro DG, Jorge JH, Varjão FM, Pavarina AC GP. Evaluation of partially dentate patients ' knowledge about caries and periodontal disease. J Gerondontology 2012;29:253-58.

https://doi.org/10.1111/j.1741-2358.2011.00460.x

91. Wright PS, Hellyer PH. Gingival recession related to removable partial dentures in older patients. J Prosthet Dent 1995;74:602-07. https://doi.org/10.1016/S0022-3913(05)80312-9

92. Chen X, Mao B, Zhu Z, Yu J, Lu Y, Zhang Q et al. A threedimensional finite element analysis of mechanical function for 4 removable partial denture designs with 3 framework materials: $\mathrm{CoCr}$, Ti-6Al-4V alloy and PEEK. Sci Rep 2019;1:1-10.

https://doi.org/10.1038/s41598-019-50363-1

93. Maninder, Rajesh. Comparative clinical evaluation of removable partial dentures made of two different materials in Kennedy Applegate class II partially edentulous situation. Med j ournal armed f orces $\mathrm{i}$ ndian 2015;71:306-12.

https://doi.org/10.1016/j.mjafi.2012.08.020

94. Bickley W. Combined splint-stress breaker removable partial denture. J pros dent 1969;21:509-12.

https://doi.org/10.1016/0022-3913(69)90072-9

95. Educ C, Dimensions N, Surg O, Jh K, Dimensions N. A photoelastic study of stress distribution mandibular split major connector. 1985; 54:220-25.

https://doi.org/10.1016/0022-3913(85)90292-6

96. Caputo AA, Ph D. A photoelastic study of a split palatal major. J pros dent1 984;54:19-23.

97. Itoh H, Caputo AA, Wylie R, Berg T, Angeles L. Effects of periodontal support and fixed splinting on load transfer by removable partial dentures. J pros dent 1998;79:465-71.

https://doi.org/10.1016/S0022-3913(98)70163-5

98. Carlon GE et al. Studies in partial pental prosthesis IV. final results of a 4-year longitudinal investigation of dentogingivally supported partial dentures. Acta Odontol Scand 1965;23:443-69. https://doi.org/10.3109/00016356509021764

99. Aydinlik E, Ph D, Dayangas B, Ph D. Effect of splinting on abutment tooth movement. J pros dent 1983;49:477-80. https://doi.org/10.1016/0022-3913(83)90306-2

100. Fernandes CP GP. he significance of major connectors and denture base mucosal contacts on the functional strain patterns of maxillary removable partial dentures. Eur J Prosthodont Restor Dent 1998; 6: 63-74.

101. Leupold J, Pfeifer DL. hree risen of vertical movement xtension removable partial impression techniques occurring denture during loading bases made by of. J pros dent 1992;65:290-93.

https://doi.org/10.1016/0022-3913(92)90332-5 


\section{Malik MHA/ Yazdanie N}

102. Sayed M, Jain S. Comparison Between Altered Cast Impression and Conventional Single-Impression Techniques for Distal Extension Removable Dental Prostheses: A Systematic Review. Int J Prosthodont 2019;32:265-71.

https://doi.org/10.11607/ijp.6198

103. C. Vanzeveren, W. D'hoore PBL. Treatment with removable partial dentures : a longitudinal study . Part I. J Oral Rehabil 2003; 30:447-58.

https://doi.org/10.1046/j.1365-2842.2003.01106.x

104. C. W. Drake J beck. The oral status of elderly removable partial denture wearers. J Oral Rehabil 1993;20:53-60.

https://doi.org/10.1111/j.1365-2842.1993.tb01514.x
Perio-prosthodontics considerations in removable partial denture: the role of the prosthodontist

105. Vermeulen AHBM. Ten-year evaluation of removable partial dentures : Survival rates based on retreatment, not wearing and replacement. J pros dent 1996;76:267-72.

https://doi.org/10.1016/S0022-3913(96)90170-5

106. Al ASB et. Clinical Practice Guidelines for Recall and Maintenance of Patients with Tooth-Borne and Implant-Borne Dental Restorations. J Dent Hyg 2016; 90:60-9. 